\title{
Pengaruh Pertumbuhan Ekonomi, Pendapatan Asli Daerah dan Dana Alokasi Umum terhadap Anggaran Belanja Modal Pemerintah Provinsi di Pulau Jawa
}

\author{
Bambang Suprayitno ${ }^{1}$ \\ ${ }^{1}$ Universitas Pancasila, Jl. Srengseng Sawah, Jagakarsa, Jakarta Selatan 12640
}

\author{
I N F O A R T I K E L \\ JEL Classification \\ H83 \\ M12
}

Keywords :

economic growth, local revenue, general allocation fundand capital expenditure.

\begin{abstract}
A B S T R A C T
This study purpose to determine the influence of Economic Growth, Local Revenue and General Allocation Fund for Capital Expenditure Provincial Government in Java the period 2009 - 2013. The method used is the method of description by using secondary data obtained from the Central Bureau of Statistics of the Republic of Indonesia. Data collection methods used were documentation with quantitative approach Analysis of this research is multiple linear regression analysis to test the influence of Economic Growth, Local Revenue and General Allocation Fund Capital Expenditure partially (t-test) and simultaneous (F-test). The results showed that partially Local Revenue and General Allocation Fund which significantly influence the Capital Expenditure, while economic growth is significant effect and negative on Capital Expenditure. Simultaneously Economic Growth, Local Revenue and General Allocation Fund effect on Capital Expenditure.
\end{abstract}

\section{A B S T R A K}

Penelitian ini bertujuan untuk mengetahui pengaruh Pertumbuhan Ekonomi, Pendapatan Asli Daerah dan Dana Alokasi Umum terhadap Belanja Modal Pemerintah Provinsi di Pulau Jawa periode 2009 - 2013. Metode penelitian yang digunakan yaitu metode deskripsi dengan menggunakan data sekunder yang diperoleh dari Badan Pusat Statistik Republik Indonesia. Metode pengumpulan data yang digunakan adalah dokumentasi dengan pendekatan kuantitatif.Analisis penelitian ini yaitu analisis regresi linear berganda menguji pengaruh Pertumbuhan Ekonomi, Pendapatan Asli Daerah dan Dana Alokasi Umum terhadap Belanja Modal.Hasil penelitian menunjukkan bahwa secara parsial Pendapatan Asli Daerah dan Dana Alokasi Umum yang berpengaruh signifikan terhadap Belanja Modal, sedangkan Pertumbuhan Ekonomi berpengaruh signifikan tetapi negatif terhadap Belanja Modal.Secara simultan Pertumbuhan Ekonomi, Pendapatan Asli Daerah dan Dana Alokasi Umum berpengaruh terhadap Belanja Modal.

\section{Pendahuluan}

Pertumbuhan ekonomi daerah merupakan salah satu indikator keberhasilan pencapaian pembangunan nasional. Dengan memperhatikan pertumbuhan ekonomi, dapat diperoleh gambaran apakah kebijakan pembangunan disuatu negara telah berorientasi terhadap pertumbuhan ekonomi

*Email Korespondensi: 'yetno_205@yahoo.com 
yang berkelanjutan sebagai salah satu kunci untuk memantapkan perekonomian nasional demi peningkatan kesejahteraan rakyat. Pertumbuhan ekonomi dapat dicapai melalui dua cara, yaitu: pertama dengan menaikan investasi modal dan kedua melakukan efisiensi terhadap sumber daya yang dimiliki. Untuk mendorong pertumbuhan ekonomi, diharapkan desentralisasi fiskal dapat memberikan dampak yang positif dan signifikan terhadap pertumbuhan ekonomi.

Menurut UU No. 32 tahun 2004 tentang pemerintah daerah, setiap daerah diberi kewenangan untuk mengurus rumah tangganya sendiri dengan sedikit mungkin adanya campur tangan dari pemerintah pusat. UU No. 32 tahun 2004 menjelaskan pula bahwa pemberian otonomi kepada pemerintah daerah untuk mempercepat terwujudnya kesejahteraan masyarakat melalui peningkatan, pelayanan, pemberdayaan, dan peran serta masyarakat, serta peningkatan daya saing daerah dengan memperhatikan prinsip demokrasi, pemerataan, keadilan, keistimewaan dan kekhususan suatu daerah dalam sistem Negara Kesatuan Republik Indonesia. Secara singkat otonomi daerah bertujuan untuk meningkatkan kesejahteraan masyarakat, pelayanan umum, dan daya saing daerah.

Melalui otonomi daerah, diharapkan mampu mendorong kemerataan pembangunan sehingga tidak terjadinya ketimpangan antara pemerintah pusat dan pemerintah daerah. Melalui otonomi daerah diharapkan dapat meningkat daya saing antar daerah dengan memperhatikan unsur pemerataan, demokrasi, keistimewaan dan kekhususan, keadilan serta potensi dan keanekaragaman daerah dalam Sistem Negara Kesatuan Republik Indonesia (Nordiawan, 2006).

\section{Telaah Teori dan Pengembangan Hipotesis}

Berdasarkan UU No. 32 tahun 2004, salah satu sumber pendapatan daerah adalah Pendapatan Asli Daerah (PAD) yang terdiri dari pajak daerah, retribusi daerah, pengelolaan kekayaan daerah yang dipisahkan dan lain-lain PAD yang sah. Peningkatan PAD diharapkan mampu meningkatkan investasi belanja modal pemerintah daerah sehingga kualitas pelayanan publik semakin baik, tetapi kenyataan yang terjadi selama ini adalah peningkatan pendapatan asli daerah tidak diikuti dengan kenaikan anggaran belanja modal yang signifikan.

Dalam rangka pelaksanaan otonomi daerah dan desentralisasi fiskal, pemerintah daerah diharapkan memiliki kemandirian yang lebih besar. Akan tetapi, saat ini masih banyak masalah yang dihadapi pemerintah daerah terkait dengan upaya meningkatkan penerimaan daerah. Pertama, tingginya tingkat kebutuhan daerah yang tidak seimbang dengan kapasitas fiskal yang dimiliki daerah, sehingga menimbulkan fiscal gap. Kedua, kualitas layanan publik yang masih memprihatinkan. Ketiga, lemahnya infrastruktur prasarana dan sarana umum. Keempat, berkurangnya dana bantuan dari pusat (DAU dari pusat yang tidak mencukupi). Terakhir, belum diketahui potensi PAD yang mendekati kondisi riil.

Kemampuan keuangan setiap daerah tidak sama dalam mendanai berbagai kegiatan, hal ini menimbulkan adanya kesenjangan fiskal antar satu daerah dengan daerah lainnya. Untuk mengatasi hal tersebut, Pemerintah mengalokasikan dana transfer yang bersumber dari APBN untuk mendanai kebutuhan daerah dalam pelaksanaan desentralisasi. Berdasarkan UU No. 32 Tahun 2004 Dana Perimbangan terdiri dari Dana Bagi Hasil (DBH), Dana Alokasi Umum (DAU), dan Dana Alokasi Khusus (DAK). Dana Alokasi Umum (DAU) merupakan salah satu dana perimbangan dari pemerintah yang pengalokasiannya menekankan aspek pemerataan dan keadilan yang selaras dengan penyelenggaraan urusan pemerintah. Dengan adanya transfer dari Pemerintah Pusat, diharapkan Pemerintah Daerah bisa lebih mampu mengalokasikan Pendapatan Asli Daerah (PAD) yang didapat untuk membiayai belanja modal. Namun pada kenyataannya, transfer dana yang bersumber dari APBN merupakan sumber pendanaan utama Pemerintah Daerah untuk membiayai operasi utamanya sehari-hari.

Dalam rangka pelaksanaan desentralisasi fiskal, pemerintah daerah mendapat bagian Pajak 
Penghasilan Perseorangan sebesar 20\% dan $80 \%$ untuk pemerintah pusat. Penerimaan Negara dari Pajak Bumi dan Bangunan (PBB) dengan imbangan 10\% untuk pemerintah pusat dan $90 \%$ untuk pemerintah daerah. Penerimaan Negara dari Bea Perolehan Hak atas Tanah dan Bangunan (BPHTB) akan dibagi dengan imbangan 20\% untuk pemerintah pusat dan $80 \%$ untuk daerah. Penerimaan pemerintah pusat dari bagi hasil PBB dan BPHTB tersebut akan dibagikan kepada seluruh Kabupaten dan Kota. Bagian daerah yang diterima pemerintah daerah yang berasal dari sumber daya alam sektor kehutanan, sektor pertambangan umum, dan sektor perikanan dibagi dengan imbangan $20 \%$ untuk pemerintah pusat dan $80 \%$ untuk daerah.

Pertumbuhan ekonomi, yang berarti perluasan ekonomi, adalah satu-satunya cara untuk meningkatkan penghasilan anggota masyarakat dan membuka lapangan kerja baru (Boediono, 2010:28). Pertumbuhan ekonomi adalah proses perubahan kondisi perekonomian suatu negara secara berkesinambungan menuju keadaan yang lebih baik selama periode tertentu. Pertumbuhan ekonomi dapat diartikan juga sebagai proses kenaikan kapasitas produksi suatu perekonomian yang diwujudkan dalam bentuk kenaikan pendapatan nasional. Adanya pertumbuhan ekonomi merupakan indikasi keberhasilan pembangunan ekonomi. Pertumbuhan ekonomi menunjukkan sejauh mana aktivitas perekonomian akan menghasilkan tambahan pendapatan masyarakat pada suatu periode tertentu.

\section{Metode}

Metode Penelitian yang digunakan penulis dalam penelitian ini adalah metode kuantitatif dan deskriptif.Analisis yang digunakan untuk pengujian hipotesis dalam penelitian ini yaitu regresi linier berganda dengan terlebih dahulu melakukan uji asumsi klasik. Variabel yang digunakan oleh penulis dala penelitian ini adalah variabel independen dan variabel dependen. Variabel bebas (Independent Variabel) variabel ini sering disebut sebagai variabel stimulus, predictor, antecedent.

Variabel Independen (bebas) dalam penelitian ini yaitu, Pertumbuhan Ekonomi yang diproyeksikan dengan PDRB per kapita, Pendapatan Asli Daerah, dan Dana Alokasi Umum yang diberi simbol X. Pertumbuhan ekonomi daerah dalam bentuk Produk Domestik Regional Bruto (PDRD). PDRB adalah jumlah produk barang dan jasa yang dihasilkan oleh berbagai unit produksi dalam suatu daerah dibagi dengan jumlah penduduk dalam jangka waktu tertentu. Dalam penelitian ini PDRB yang digunakan adalah PDRB atas dasar harga konstan tahun 2000 yang dinyatakan dalam rupiah.PDRB atas dasar harga berlaku menggambarkan nilai tambah barang dan jasa yang dihitung menggunakan harga yang berlaku pada setiap tahun.Skala pengukuran yang dipakai pertumbuhan ekonomi dalam penelitian ini adalah skala ratio.Pendapatan Asli Daerah dalam penelitian ini dapat diketahui dari pos pendapatan daerah dalam laporan realisasi APBD pemerintah Provinsi di pulau Jawa selama 5 tahun terakhir. Rumus untuk menghitung pendapatan asli daerah adalah: $\mathrm{PAD}=$ Pajak Daerah + Retribusi Daerah + Hasil Pengelolaan Kekayaan Daerah Yang Dipisahkan + Lain - lain PAD Yang Sah.Dana Alokasi Umum diperoleh dengan melihat dari dana perimbangan yang ada di laporan realisasi APBD pemerintah Provinsi di pulau Jawa selama 5 tahun terakhir. Variabel Dependen (tidak bebas) dalam penelitian ini adalah belanja modal provinsi di pulau Jawa melalui APBD yang diberi simbol Y.

\section{Hasil dan Pembahasan}

Berdasarkan data Badan Pusat Statistik Republik Indonesia mengenai Laporan Realisasi Anggaran Pendapatan dan Belanja Daerah untuk informasi Pendapatan Asli Daerah (PAD), Dana Alokasi Umum (DAU) dan Belanja Modal, serta data Pertumbuhan Ekonomi Provinsi di Pulau Jawa tahun 2009-2013 sebagai berikut: 
Tabel 1.Hasil Perhitungan Deskriptif Statistik

(dalam jutaan)

\begin{tabular}{rrrrr}
\hline \multicolumn{1}{c}{ Variabel } & Minimum & Maximum & \multicolumn{1}{c}{ Mean } & Std. Deviation \\
\hline BM & 0.13 & 11.38 & 2.18 & 3.22 \\
GROWTH*) $^{*}$ & 0.04 & 0.072 & 0,06 & 0,008 \\
PAD & 0.60 & 26,85 & 7.25 & 6.24 \\
DAU & 0.00 & 27,12 & 1.72 & 4.82 \\
\hline
\end{tabular}

Berdasarkan deskriptif statistik pada Tabel 1 nilai rata-rata belanja modal adalah 2.18 juta rupiah data entry. Adapun nilai pendapatan asli daerah dan dana alokasi umum masing-masing sebesar 7,25 juta rupiah satuan data entry dan 4,82 juta rupiah satuan data entr $y$. Angka growth merupakan pertumbuhan ekonomi provinsi, dimana nagka pertumbuhan rata-rata selama periode penelitian adalah sebesar 0.06 .

Pengujian asumsi klasik dilakukan untuk mengupayakan model terbaik untuk penelitian. Pengujian mencakup, Uji Normalitas, autokorelasi, multikolinearitas, dan heteroskedastisitas. Uji Normalitas digunakan untuk mengetahui apakah dalam model regresi, variabel pengganggu atau residual (perbedaan yang ada) yang diteliti memiliki distribusi normal atau tidak normal. Pengujian dilakukan dengan Uji OneSample Kolmogorov Smirnov. Uji autokorelasi digunakan untuk mengetahui ada tidaknya korelasi antara anggota serangkaian data yang diobservasi dan dianalisis menurut ruang atau menurut waktu.Uji ini bertujuan menguji apakah dalam model regresi linear berganda ada korelasi antara kesalahan pengganggu pada periode $t$ dengan kesalahan pengganggu pada periode $\mathrm{t}-1$ (sebelumnya). Uji autokorelasi yang digunakan dalam penelitian ini adalah Durbin-
Watson (DW). Hasil perhitungan dapat disimpulkan jika nilai Durbin Watson berada pada range nilai du hingga (4-dU) maka ditarik kesimpulan bahwa model tidak terdapat autokorelasi.

Dalam persamaan regresi tidak boleh terjadi multikolinearitas, artinya tidak boleh ada korelasi atau hubungan yang sempurna atau mendekati sempurna antar variabel bebas yang membentuk persamaan tersebut. Jika pada model persamaan tersebut terjadi gejala multikolinearitas, maka sesama variabel bebasnya terjadi korelasi. Cara untuk mengetahui apakah suatu variabel memiliki korelasi dengan variabel lainnya pada penelitian ini adalah dengan melihat nilai Variance Inflation Factor (VIF), jika VIF kurang dari 10 menunjukkan model tidak terdapat gejala multikolinearitas atau tidak terdapat hubungan antara variabel bebas. Uji heteroskedastisitas diperlukan untuk menguji ada tidaknya gejala heteroskedastisitas yang berarti terjadi ketidaksamaan varian dari residual pada pengamatan model regresi. Rangkuman hasil uji asumsi klasik, sebagaimana tampak pada Tabel 2.

Berdasarkan hasil Uji heteroskedastisitas menggunakan diperoleh grafik scatter plot pada gambar 1.

Tabel 2.

Hasil Uji Asumsi Klasik

\begin{tabular}{lrr}
\hline \multicolumn{1}{c}{ Pengujian } & Hasil Uji & \multicolumn{1}{c}{ Keterangan } \\
\hline $\begin{array}{l}\text { Uji Normalitas } \\
\text { (Kolmogorov Sirnov) }\end{array}$ & 0.808 & Normal \\
$\begin{array}{l}\text { Uji Autokorelasi } \\
\text { (Durbin Watson tesit) }\end{array}$ & 3.089 & Tidak terjadi autokorelasi \\
$\begin{array}{l}\text { Uji Multikolinearitas } \\
\text { (Variance Inflation Factor) }\end{array}$ & Growth:1,335; PAD=1,329; DAU=1,005 & Tidak terjadi multikolinearitas \\
\hline
\end{tabular}




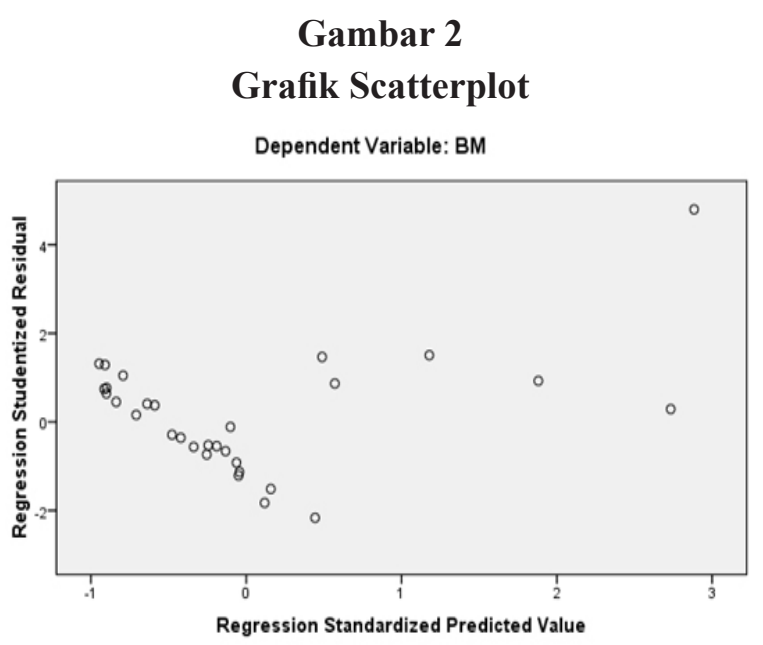

Dari Gambar 2 terlihat titik-titik tidak menyebar pada grafik secara acak ke segala arah dan membentuk pola tertentu. Dengan demikian, dapat disimpulkan bahwa model regresi terjadi heteroskedastisitas.

Analisis regresi linear berganda akan memberikan hasil yang baik jika dalam model tersebut, data memiliki distribusi normal dan memenuhi uji asumsi klasik. Uji ini dilakukan untuk melihat pengaruh Pertumbuhan Ekonomi, Pendapatan Asli Daerah dan Dana Alokasi Umum terhadap Belanja Modal Pemerintah Provinsi di Pulau Jawa. Hasil pengujian tampak pada Tabel 3.

Tabel 3

\section{Hasil Pengujian Hipotesis}

\begin{tabular}{lll}
\hline \multicolumn{1}{c}{ Variabel } & \multicolumn{1}{c}{ t-hitung } & \multicolumn{1}{c}{ Sig. } \\
\hline (Constant) & 2.116 & .044 \\
GROWTH & -2.927 & .007 \\
PAD & 11.888 & .000 \\
DAU & 7.579 & .000 \\
Adj-R square & 0.878 & \\
F-hitung & 70.462 & \\
Sig. & $.000 \mathrm{a}$ & \\
\hline
\end{tabular}

Uji $\mathrm{F}$ digunakan untuk mengetahui pengaruh secara simultan variabel independen terhadap variabel dependen. Pengujian ini digunakan untuk menguji apakah model fit atau tidak, demikian juga dengan uji koefisien determinasi (Adj. R-square). Nilai koefisien determinasi menunjukkan kemampuan variable independen menjelaskan dependen variable. Hasil uji F menunjukkan bahwa keempat variabel independen Pertumbuhan Ekonomi (GROWTH), Pendapatan Asli Daerah (PAD) dan Dana Alokasi Umum (DAU) secara simultan berpengaruh terhadap Belanja Modal Pemerintah Provinsi di Pulau Jawa, dimana F hitung sebesar 70,462 dengan tingkat signifikansi (angka probabilitas) sebesar 0,000. Karena nilai $\mathrm{F}$ hitung lebih besar dari $\mathrm{F}$ tabel ( $\mathrm{F}$ hitung 70,462 $>\mathrm{F}$ tabel 2,98) dengan angka probabilitas $0,000<0,05$.

Nilai Adjusted R Square sebesar 0,878 atau sama dengan $87,5 \%$. Angka tersebut menunjukkan bahwa sebesar 87,5\% Belanja Modal dipengaruhi oleh Pertumbuhan Ekonomi, Pendapatan Asli Daerah dan Dana Alokasi Umum. Sementara sebesar 12,2\% dipengaruhi oleh faktor-faktor lain yang tidak dimasukkan dalam penelitian ini.

Hasil Uji t menunjukkan pengaruh masing-masing variable independen terhadap dependen variable. Pada penelitian ini adalah pengaruh pertumbuhan ekonomi, pendapatan asli daerah dan dana alokasi umum terhadap belanja modal. Hasil pengujian menunjukkan:

1. Hipotesis alternatif pertama (H1) menyatakan bahwa Pertumbuhan Ekonomi memiliki pengaruh positif terhadap belanja modal pemerintah Provinsi di Pulau Jawa. Hasil pengujian statistik menunjukkan bahwa tingkat signifikansi t sebesar 0,007 lebih kecil dari $0,05(0,007<0,05)$. Nilai $t$ hitung lebih besar dari $t$ tabel ( $\mathrm{t}$ hitung-2,927 < $\mathrm{t}$ tabel 2,0518). Dengan demikian, H0 diterima dan $\mathrm{H} 1$ ditolak. Dapat disimpulkan bahwa Pertumbuhan Ekonomi (GROWTH) memiliki pengaruh yang signifikan tetapi negatif terhadap Belanja Modal.

2. Hipotesis alternatif kedua (H2) meyatakan bahwa Pendapatan Asli Daerah (PAD) memiliki pengaruh positif terhadap belanja modal pemerintah provinsi di pulau Jawa. Hasil pengujian statistik menunjukkan bahwa tingkat signifikansi t sebesar 0,000 lebih kecil dari $0,05(0,000<0,05)$. Nilai $\mathrm{t}$ hitung lebih besar dari ttabel ( $\mathrm{t}$ hitung 11,888 $>$ 2,0518). Dengan demikian H0 ditolak 
dan H1 diterima. Dapat disimpulkan bahwa Pendapatan Asli Daerah memiliki pengaruh yang signifikan dan positif terhadap Belanja Modal pemerintah Provinsi di Pulau Jawa.

3. Hipotesis alternatif ketiga (H3) menyatakan bahwa Dana Alokasi Umum (DAU) memiliki pengaruh positif terhadap Belanja Modal pemerintah Provinsi di Pulau Jawa. Hasil pengujian statistik menunjukkan bahwa tingkat signifikansi t sebesar 0,000 lebih kecil dari $0,05(0,000<0,05)$. Nilai thitung lebih besar dari ttabel (thitung 7,579 $>2,0518$ ). Dengan demikian H0 ditolak dan H3 diterima. Dapat disimpulkan bahwa Dana Alokasi Umum memiliki pengaruh yang signifikan dan positif terhadap Belanja Modal Pemerintah Provinsi di Pulau Jawa.

Hasil penelitian menyatakan bahwa Pertumbuhan Ekonomi berpengaruh signifikan tetapi negatif terhadap Belanja Modal.Artinya angka Pertumbuhan Ekonomi yang meningkat tidak diikuti oleh peningkatan Belanja Modal. Hal ini dapat terjadi karena alokasi Belanja Modal suatu daerah didasarkan pada kebutuhan daerah akan sarana dan prasarana baik untuk kelancaran pelaksanaan tugas pemerintah maupun untuk fasilitas publik, sedangkan perubahan Pertumbuhan Ekonomi suatu daerah disebabkan oleh perubahan PDRB melalui peningkatan jumlah produksi barang dan jasa yang dibandingkan dengan jumlah penduduk suatu daerah. Hasil penelitian ini tidak sesuai dengan hasil penelitian yang dilakukan oleh Arwati dan Hadiati (2011), Setiawan \& Wahyudi (2011); Adi (2006), Mirza (2012) yang menunjukkan bahwa Pertumbuhan Ekonomi tidak berpengaruh signifikan terhadap Belanja Modal.

Hasil penelitian ini menyatakan bahwa Pendapatan Asli Daerah (PAD) berpengaruh signifikan dan positif terhadap Belanja Modal. Artinya, semakin tinggi Pendapatan Asli Daerah yang diterima oleh Pemerintah Provinsi dalam penelitian ini, maka hal tersebut (PAD) akan berpengaruh terhadap meningkatnya jumlah Belanja Modal. Hasil penelitian ini sesuai dengan penelitian yang dilakukan Pelealu (2013), Handayani dan Nuraina (2012), Arwati dan Hadiati (2011), Kurniawati (2011), Adi (2007) yang menyebutkan bahwa Pendapatan Asli Daerah (PAD) berpengaruh signifikan terhadap Belanja Daerah, dan sesuai dengan hasil penelitian Arwati dan Hadiati (2011) yang menyebutkan bahwa Pendapatan Asli Darah (PAD) berpengaruh signifikan terhadap Belanja Modal. Belanja Modal Pemerintah Provinsi dalam penelitian ini yang adalah Pemerintah Provinsi di Pulau Jawa yang tentu tidak terlepas dari sumber penerimaan Provinsi yang berasal dari Pendapatan Asli Daerah yang telah direncanakan dalam APBD dan direalisasikan. Hasil penelitian ini tak konsisten dengan Sasana (2011) yang memberikan temuan sebaliknya terhadap Belanja Daerah..

Hasil penelitian ini menyatakan bahwa Dana Alokasi Umum berpengaruh signifikan dan positif terhadap Belanja Modal Pemerintah Provinsi di Pulau Jawa. Artinya, pada saat terjadi peningkatan jumlah Dana Alokasi Umum akan berpengaruh pada peningkatan jumlah Belanja Modal. Hasil penelitian ini tidak sesuai dengan hasilpenelitianyang dilakukanoleh Sasana(2011), yang menyatakan bahwa Dana Alokasi Umum (DAU) yang diterima oleh Pemerintah Daerah berpengaruh pada meningkatnya Belanja Daerah. Dana Alokasi Umum (DAU) memiliki persentase yang cukup besar dibandingkan penerimaan daerah lainnya. Jumlah ini mengindikasikan, bahwa Belanja Modal masih bergantung pada Transfer Pemerintah Pusat kepada Pemerintah Daerah. Transfer ini bermaksud untuk mengoptimalkan pelaksanaan otonomi daerah bilamana terjadi ketidakseimbangan antara penerimaan dan pengeluaran suatu daerah. Hasil penelitian berlawanan arah dengan Mawarni, dkk (2013) yang memberikan bukti bahwa DAU berpengaruh negatif terhadap Belanja Modal.

\section{Simpulan, Keterbatasan dan Implikasi Hasil Penelitian}

Setelah dilakukan analisis dan pengujian hipotesis pada bab sebelumnya, berikut kesimpulan yang dapat diambil adalah sebagai berikut: 
1. Pertumbuhan Ekonomi berpengaru signifikan tetapi negatif terhadap Belanja Modal Pemerintah Provinsi di Pulau Jawa periode 2009-2013. Hal ini menunjukkan, semakin besar Pertumbuhan Ekonomi tidak meningkatkan Belanja Madal pemerintah Provinsi di Pulau Jawa.

2. Pendapatan Asli Daerah (PAD) berpengaruh signifikan dan positif terhadap Belanja Modal Pemerintah Provinsi di Pulau Jawa periode 2009-2013. Hal ini menunjukkan, semakin besar jumlah Pendapatan Asli Daerah (PAD) yang diterima Pemerintah Provinsi, maka semakin besar pula Belanja Modal Pemerintah Provinsi di Pulau Jawa.

3. Dana Alokasi Umum (DAU) berpengaruh signifikan dan positif terhadap Belanja Modal Pemerintah Provinsi di Pulau Jawa periode 2009-2013. Artinya, semakin besar jumlah Dana Alokasi Umum yang diperoleh Pemerintah Provinsi maka akan semakin besar pula Belanja Modal Pemerintah Provinsi di Pulau Jawa.

4. Pertumbuhan Ekonomi, Pendapatan Asli Daerah (PAD) dan Transfer Pemerintah Pusat dalam bentuk Dana Alokasi Umum (DAU mempunyaipengaruh terhadapBelanja Modal Pemerintah Provinsi di Pulau Jawa periode 2009-2013. Hal ini menunjukkan, semakin besar Pertumbuhan Ekonomi, Pendapatan Asli Daerah (PAD) dan Dana Alokasi Umum (DAU) yang diperoleh Pemerintah, maka semakin besar pula Belanja Modal yang dilakukan Pemerintah Provinsi di Pulau Jawa.

\section{Daftar Pustaka}

Adi, P., H., 2006. Hubungan Antara Pertumbuhan Ekonomi Daerah, Belanja Pembangunan Dan Pendapatan Asli Daerah. Dalam Simposium Nasional Akuntansi IX Padang.

Arwati,D., Hadiati,N., 2013, Pengaruh Pertumbuhan Ekonomi, Pendapatan Asli Daerah dan Dana Alokasi Umum Terhadap Pengalokasian Anggaran Belanja Modal pada Pemerintah Daerah Kabupaten/Kota di Provinsi Jawa
Barat. Seminar Nasional Teknologi Informasi \& Komunikasi

Handayani, D., Nuraina, E., 2012. Pengaruh Pajak Daerah dan Dana Alokasi Khusus Terhadap Alokasi Belanja Daerah Kabupaten Madiun. Dalam Jurnal Akuntansi Dan Pendidikan, 11, 1-12.

Kurniawati, F. R., 2010. Pengaruh Dana Alokasi Umum DAU dan Pendapatan Asli Daerah Pad Terhadap Belanja Pemerintah Daerah Provinsi, Kota, Dan Kabupaten Di Indonesia, Universitas Sebelas Maret.

Mawarni, D., \& Abdullah, S., 2013, Pengaruh Pendapatan Asli Daerah dan Dana Alokasi Umum Terhadap Belanja Modal Serta Dampaknya Terhadap Pertumbuhan Ekonomi Daerah (Studi Pada Kabupaten dan Kota di Aceh). Jurnal Akuntansi ISSN, 2302, 0164.

Mirza, D. S., 2012, Pengaruh Kemiskinan, Pertumbuhan Ekonomi, Dan Belanja Modal Terhadap Indeks Pembangunan Manusia di Jawa Tengah Tahun 2006-2009. Economics Development Analysis Journal, 1(2).

Nordiawan, Deddi. 2006. Akuntansi Sektor Publik. Jakarta : Salemba Empat.

Pelealu, A. M., 2013. Pengaruh Dana Alokasi Khusus DAK, Dan Pendapatan Asli Daerah PAD Terhadap Belanja Modal Pemerintah Kota Manado Tahun 2003-2012. Jurnal Riset Ekonomi, Manajemen, Bisnis Dan Akuntansi, 14.

Prakoso, Kesit Bambang. 2004. Skripsi.Analisis pengaruh Dana Alokasi Umum (DAU) dan Pendapatan Asli Daerah (PAD) dan Dana Alokasi Khusus terhadap Anggaran Belanja Modal pada Pemko/Pengkab Sumatra Utara. Medan: Sekolah Pascasarjana Universitas Sumatera Utara.

Sasana, H., 2011. Analisis Determinan Belanja Daerah Di Kabupaten/Kota Provinsi Jawa Barat Dalam Era Otonomi Dan Desentralisasi Fiskal. Jurnal Bisnis Dan Ekonomi, 181.

Setiawan, A., Wahyudi, S., 2011. Pengaruh Dana Alokasi Umum DAU dan Pendapatan Asli Daerah Pad Terhadap Belanja Daerah Studi Kasus Pada Provinsi Jawa Tengah Doctoral Dissertation, Universitas Diponegoro. 